УДК 371.134:004.383.8

\author{
Юрченко Валерій, \\ кандидат технічних наук, доцент, \\ ORCID iD 0000-0003-2238-1206 \\ E-mail: valaleks@ukr.net
}

\title{
ВИКОРИСТАННЯ ІННОВАЦИЙНИХ ФОРМ ЗДОБУТТЯ ОСВІТИ В СИСТЕМІ ПІДГОТОВКИ ДЕРЖАВНИХ СЛУЖБОВЦІВ І ПОСАДОВИХ ОСІБ МІСЦЕВОГО САМОВРЯДУВАННЯ
}

\section{https://doi.org/10.32689/2618-0065-2021-1(7)-303-317}

\begin{abstract}
Анотація. У статті розглянуто форми здобуття освіти для професійної підготовки державних службовців та посадових осіб місцевого самоврядування (далі - державні службовці), зокрема за інституційною (очною,дистанційною, мережевою, змішаною, дуальною та на робочому місці) формою навчання.

На основі аналізу положень Меморандуму безперервної освіти Свропейської Комісії dстановлено, на яких основних принципах повинна базуватись нова модель професійного навчання державних службовців.

Детально проаналізовано основні форми здобуття освіти зазначеною категорією слухачів, переваги та недоліки очної, дистанційної, мережевої, змішаної, дуальної та на робочому місці форм навчання.

Проаналізовано деякі моделі організації змішаного навчання для підготовки державних службовців, зокрема визначено доцільність застосування моделі «перевернутого класу», як однієї з ефективних форм здобуття освіти зазначеною категорією слухачів.

Розглянуто рекомендації Міністерства науки і освіти України щодо впровадження змішаного навчання у закладах фахової передвищої та вищої освіти.

Запропоновано ефективну форму здобуття освіти для професійної підготовки державних службовців, яка враховує всі переваги та зводить на нівець основні недоліки розглянутих у статті форм здобуття освіти.

Визначено напрями подальших досліджень щодо покращення якості та ефективності навчання державних службовців, зокрема у більш детальному розгляді переліку компетентностей державних службовців, які можуть розвиватися тільки за допомогою аудиторного навчання, компетентностей, які доцільно розвивати за допомогою самонавчання 3 використанням електронних ресурсів, а також компетентностей, які необхідно розвивати за допомогою навчання на робочому місці.
\end{abstract}

Ключові слова: підготовка державних службовців, форми здобуття освіти, змішане навчання, якість та ефективність навчання, моделі змішаного навчання. 
Постановка проблеми. Реформування державного управління, державної служби, місцевого самоврядування та територіальної організації влади вимагає високого рівня професійної компетентності та професійного розвитку державних службовців [1].

Система підготовки, спеціалізації та підвищення кваліфікації (далі - система професійного навчання) державних службовців повинна відповідати сучасним вимогам до якості та змісту освіти. Звичайно, перш за все це стосується змісту освітньо-професійних програм підготовки (далі - ОПП) фахівців за спеціальністю “Публічне управління та адміністрування", професійних програм підвищення кваліфікації (далі - ПППК), які повинні враховувати цілі та завдання, які стоять перед державними службовцями.

В той самий час, до кінця не вирішені питання: за якими формами здобуття освіти якісно та ефективно організовувати систему професійного навчання державних службовців окремих державних органів, наразі в сфері цивільного захисту.

Проблемам, що виникають на сучасному етапі організації системи професійного навчання зазначених категорій слухачів за умови використання інформаційно-комунікаційних технологій, шляхам їх вирішення присвячена дана публікація.

Аналіз останніх досліджень і публікацій. Теоретичні та практичні аспекти реалізації змішаного навчання розглядаються в роботах вітчизняних та зарубіжних учених: А. Стрюка, О. Рафальської, Н. Рашевської, М. Хорна, Х. Стейкер, К. Кеннеді, Е. Пауел, Б. Ребіт, С. Патрік та ін. К. Бугайчук [3], В. Кухаренко [4], І. Столяренко [5], С. Касьян, В. Олійник, Л. Ляховська [6] у своїх роботах більш детально розглянули питання теорії та практики змішаного навчання як навчального середовища нового покоління.

Проблематиці інноваційних методів в системі підготовки державних службовців у сфері цивільного захисту присвячені дослідження А. Терент'євої, О. Свсюкова, Є. Литвиновського та iн. науковців Інституту державного управління та наукових досліджень $з$ цивільного захисту. 


\section{Науковий вісник : Державне управління №1 (7) 2021}

Так, Є. Литвиновський обгрунтував ефективність застосування методу кейс-стаді в системі підготовки фахівців цивільного захисту [7, с. 169]. Також запропонував на базі використання хмарних інформаційних технологій та он-лайн сервісу «Google+» створити єдине освітнє середовище - хмарну платформу методичного забезпечення навчальних установ цивільного захисту. Автор зазначає, що «...Створення віртуального навчально-методичного об'єднання «Освітній простір безпеки життєдіяльності», дозволить: забезпечити єдиний освітній простір єдиною інформаційно-комунікаційною платформою обміну, в першу чергу, електронними освітніми ресурсами; створити можливості інтегрованого пошуку та доступу до знань, що накопичуються в кожному освітньому закладі» [7, с. 192]. Отже, запропонував підхід, який можна використовувати для дистанційного та змішаного навчання

О. Свсюков, А. Гаваза до інноваційних технологій навчання у сучасній системі підвищення кваліфікації управлінських кадрів відносять: технологію програмованого навчання; медіатехнологію та мережеву технологію як види дистанційного навчання. В розвиток кейс-технології визначають іiі як вид дистанційної технології навчання, яка заснована на використанні наборів (кейсів) текстових, аудіовізуальних та мультимедійних навчально-методичних матеріалів для їх самостійного вивчення слухачами при організації регулярних консультацій у викладачів (тьюторів) традиційним або дистанційним способом [8, с. 111112].

Колектив авторів кафедри державного управління цивільним захистом на чолі з професором Терент'євою А.В., перспективним шляхом удосконалення та оптимізації навчального процесу вважають використання мультимедійної системи. Мультимедіа, зазначають автори «...дає змогу інтенсифікувати процес навчання, надати йому динамізму, гнучкості, посилити його прикладну спрямованість. ... Мультимедіа розуміється як сучасна комп"терна технологія, що дозволяє об'єднати в комп'ютерній системі текст, звук, відеозображення, графічні зображення й анімацію. Використання віртуальної реальності у педагогічному 
процесі породжує ефект присутності, а це робить можливим змінити всю систему навчання й виховання» [9, с. 117].

Проте питання визначення форм здобуття освіти для якісної підготовки державних службовців в сучасних умовах залишається не дослідженим.

Постановка завдання. Метою дослідження $\epsilon$ аналіз інноваційних форм здобуття освіти для якісного навчання державних службовців.

Виклад основного матеріалу. Сучасна ефективна система професійного навчання державних службовців, яка забезпечить підвищення рівня їх професійної компетентності, повинна бути зорієнтована на потреби особистості у професійному розвитку протягом усього життя та сприяти впровадженню принципів належного врядування [10].

Професійний розвиток державних службовців - це безперервний, свідомий, цілеспрямований процес особистісного та професійного зростання, що базується на інтеграції знань, умінь і компетентності.

Система професійного навчання повинна, насамперед, бути цілісною сукупністю взаємопов'язаних компонентів, що включає формування мотивації у державних службовців до підвищення рівня професійної компетентності.

3 урахуванням положень Меморандуму безперервної освіти Свропейської Комісії нова модель професійного навчання державних службовців повинна базуватись на таких основних принципах [1]:

наближеність освітніх послуг до місця проживання та роботи особи;

обов'язковість, безперервність та забезпечення умов до самоосвіти та професійного розвитку протягом усього життя;

цілеспрямованість, прогностичність та випереджувальний характер;

інноваційність та практична спрямованість;

індивідуалізація та диференціація підходів до навчання;

відкритість;

гарантованість фінансування професійного навчання. 
Тобто передбачається налагодження повноцінної та ефективної системи професійного навчання державних службовців.

Відповідно до зазначеного виникає наукова проблема пошуку інноваційних форм здобуття освіти доцільно застосувати під час організації освітнього процесу, щоб на практиці реалізувати основні принципи для створення нової моделі професійного навчання державних службовців в Україні.

Згідно чинного законодавства професійні програми підвищення кваліфікації можуть передбачати очну (денну, вечірню), дистанційну та змішану (очну та дистанційну 3 використанням спеціальних інтернет-платформ, веб-сайтів тощо) форми навчання.

Професійне навчання може здійснюватися шляхом самоосвіти у формі участі у науково-практичних конференціях, фахових семінарах, тренінгах, майстер-класах, курсах 3 оволодіння практичними навичками тощо.

У Законі України «Про освіту»(ст. 9) передбачено три форми здобуття освіти, серед них - інституційна. Під інституційною формою здобуття освіти розуміють освіту, яку здобувають: очно (денна й вечірня форми), заочно, дистанційно, мережево [2].

Однак потрібно розуміти, що це не вичерпний механізм, і для побудови освітньої траєкторії для конкретної категорії слухачів необхідно розробляти й інші формати.

Для вирішення зазначеної проблеми було проаналізовано процес підготовки та підвищення кваліфікації державних службовців (отримання професійних знань, набуття необхідних компетентностей для зазначених посадових осіб за наступними формами навчання: аудиторне (інституційна, денна); дистанційна; на робочому місці; самостійна 3 використанням електронних ресурсів; дуальна; мережево.

Під час аудиторного навчання виникають такі проблеми: затримка фінансування, відсутність умов для практичного відпрацювання навчальних питань, відсутність індивідуалізації та диференціації підходів до навчання, відсутність наближеності освітніх послуг до місця проживання та роботи особи. 
Перевагами можна вважати: відкритість, забезпечення умов до самоосвіти, цілеспрямованість, прогностичність та випереджувальний характер.

Якщо застосовувати тільки дистанційну форму навчання, то маємо проблему щодо практичної спрямованості навчання. Але отримуємо перелік переваг, таких як наближеність освітніх послуг до місця проживання та роботи особи (умовно, за рахунок використання інформаційних мереж для створення навчального контенту i використання різноманітних інструментів на електронній освітній платформі Moodle), обов'язковість, безперервність та забезпечення умов до самоосвіти та професійного розвитку протягом усього життя, цілеспрямованість, прогностичність та випереджувальний характер, інноваційність, індивідуалізація та диференціація підходів до навчання, відкритість. До переваг дистанційної форми навчання також можна віднести гнучкий графік та темп навчання. Що стосується фінансування дистанційної форми навчання, то воно за рахунок економії коштів на оплату за переїзд в обидві сторони до закладу вищої освіти (далі - 3ВО) та у зворотному напрямі, проживання у готелі, харчування, комунальні розрахунки та інше на $30-40 \%$ менше від аудиторного. I ще на один недолік дистанційної форми навчання треба вказати. Вона посилює соціальну ізольованість, але в умовах карантину у зв'язку з поширенням COVID-19 цей недолік дистанційної форми навчання становиться перевагою.

Наступна форма здобуття освіти - самоосвіта 3 використанням електронних ресурсів. Перевагами можна вважати: наближеність освітніх послуг до місця проживання та роботи особи (умовно, за рахунок використання інформаційних мереж), обов'язковість, безперервність та забезпечення умов до самоосвіти та професійного розвитку протягом усього життя, цілеспрямованість, прогностичність та випереджувальний характер, інноваційність, індивідуалізація та диференціація підходів до навчання. Щодо проблем, які можуть виникнути. Це перш за все, питання забезпечення умов до самоосвіти та професійного розвитку протягом усього життя. За рахунок якого 
робочого часу посадова особа буде займатись самоосвітою? Яким чином буде здійснюватись фінансування зазначеної форми навчання? Яким нормативним або розпорядчим документом буде підтверджено отримання знань і хто його надасть?

Механізм впровадження мережевої форми здобуття освіти має свої особливості. Він дає ЗВО реальний інструмент для взаємодії із закладами культури, фізкультури і спорту, ресурсними центрами та іншими суб'єктами освітньої діяльності. Ця форма навчання надає можливість 3ВО підвищувати кваліфікацію державним службовцям за окремими навчальними програмами враховуючи їх спеціалізацію. Прикладом може бути організація функціонального навчання 3 питань цивільного захисту, коли під час складання навчальних програм враховується специфіка конкретного міністерства, відомства, організації, установи, підприємства або конкретного регіону 3 його природними та техногенними особливостями. Переваги такі: мінімальний відрив робочого персоналу від виконання своїх службових обов'язків, наближеність освітніх послуг до місця проживання та роботи особи, інноваційність та практична спрямованість. Треба враховувати, що організація мережевого навчання можлива за умови гарантованості фінансування професійного навчання. Недоліком, як правило, є відсутність належної якісної навчально-методичної бази, обладнаних навчальних аудиторій за місцем проведення занять.

Наступна можлива форма отримання знань державним службовцем - це дуальна, тобто під час якого теоретична частина підготовки проходить на базі ЗВО [12], а практична - на робочому місці. Зазначена форма навчання має наступні переваги: обов'язковість, безперервність, забезпечення умов до самоосвіти та професійного розвитку протягом усього життя, цілеспрямованість, прогностичність, інноваційність та практична спрямованість, індивідуалізація та диференціація підходів до навчання, відкритість.

До недоліків відносяться: віддаленість освітніх послуг до місця проживання та роботи особи, негарантованість фінансування професійного навчання (враховуючи значну 


\section{Науковий вісник : Державне управління №1 (7) 2021}

вартість використання аудиторій 3ВО, вартість квитків на переїзди, проживання в готелі та харчування).

Навчання безпосередньо на робочому місці характеризується взаємодією слухача 3 роботою у звичайній виробничій ситуації. Характерною ознакою такої підготовки $\epsilon$ те, що вона, проводиться спеціально для певної організації та лише для іï персоналу.

Безумовно, найкраще навчання відбувається під час виконання нових функціональних обов'язків на робочому місці.

Для більш досвідчених фахівців-державних службовців може бути передбачена індивідуальна програма підвищення рівня професійної компетентності (далі - індивідуальна програма) документ, що визначає індивідуальні потреби державного службовця у професійному навчанні, форму та види проходження такого навчання [10].

Умови навчання на робочому місці повиннідозволяти співробітникові отримувати необхідні знання та навички безпосередньо в процесі виконання своїх професійних обов'язків 3 метою підвищення власної компетентності, i, як наслідок, ефективності функціонування всієї організації.

Для цього повинні бути обрані компетентності, які, поперше, можуть розвиватися тільки за допомогою аудиторного навчання, по-друге, доцільно розвивати за допомогою самонавчання 3 використанням електронних ресурсів, по-третє, ті, які можна розвинути за допомогою навчання на робочому місці. Зрозуміло, що деякі компетентності набагато простіше пропрацювати в рамках самостійного розвитку з використанням електронних ресурсів, деякі компетентності вимагають виняткової роботи над ними під час тренінгу (наприклад, розвиток компетентностей, пов'язаних із взаємодією та співпрацею), а деякі взагалі не мають сильного впливу на результати службової діяльності, у зв'язку з чим спеціально розвивати їх недоцільно.

Проведений аналіз показав такі результати: оптимальним варіантом форми здобуття освіти для державних службовців $є$ комбінація дуальної та дистанційної форми навчання, тобто - 
один із варіантів змішаного навчання (далі - 3Н), який вдало поєднує переваги традиційного та дистанційного навчання, позбувшись їх недоліків.

Традиційно ЗН проходить у три етапи [3]: самостійне вивчення матеріалу, аудиторне інтерактивне заняття i продовження інтерактивного навчання та підтримки на робочому місці.

Під час ЗН слухачі мають можливість вибору форм та методів роботи з навчальним матеріалом, встановлення власного темпу навчання. ЗН надає можливості для інтенсивного обміну ідеями, поглядами, переконаннями всіх учасників навчальновиховного процесу, їх активну взаємодію, спрямовану на досягнення індивідуальних та групових освітніх цілей, забезпечує постійний зворотній зв'язок між викладачем та слухачами. $3 \mathrm{H}$ надає широкий спектр можливостей для підвищення мотивації слухачів до навчання: створення комфортного навчального середовища, реалізація постійного зворотного зв'язку між викладачем та слухачами, підтримка активної взаємодії всіх учасників процесу навчання [5,6].

ЗН може здійснюватися за такими формами: синхронні очні форми (лекції, семінари, практичні заняття тощо); синхронні дистанційні форми (віртуальні класи, вебінари, коучінг, обмін миттєвими повідомленнями тощо); асинхронні форми (навчання 3 використання електронної системи підтримки навчанням, оцінювання знань (тестування. опитування), робота 3 документами та вебсторінками, відео та аудіо записами, спілкування через електронну пошту, Skype, в навчальних інтернет-спільнотах, дискусійних форумах тощо) [4-6].

На нашу думку, у процесі навчання державних службовців необхідно попередньо самостійно ознайомитися 3 новим матеріалом, що постачається в електронному вигляді, а на заняттях під керівництвом викладача відбувається закріплення отриманих знань (модель «перевернутого класу»). Для полегшення сприйнятя навчального матеріалу використовуються презентації, електронні дошки тощо. 
Перераховані вище переваги ЗН покращують та стимулюють процес навчання, але наскільки воно буде ефективним багато в чому залежатиме саме від викладачів. У ЗН викладач виступає як організатор різних видів навчальної діяльності. Він повинен постійно здійснювати підтримку, консультування слухачів в процесі навчання, яка може здійснюватися як очно, так i дистанційно.

Разом 3 тим, слід зазначити, що організація ЗН потребує вирішення 3ВО непростих організаційних, методичних та навчальних завдань, а саме [11]:

вибір моделі ЗН, яка повинна працювати на розв'язання конкретних завдань, щопоставленінавчальним закладом;

організація технічного забезпечення.

формування кадрової складової (підготовка викладачів для роботи у форматі змішаного навчання).

забезпечення методичної та нормативної підтримки (розробка методичних рекомендацій і нормативних вимог до організації освітнього процесу за моделю змішаного навчання).

Це стосується розподілу матеріалу на «он-лайн» та «очну частину», розробки інструктивних матеріалів для викладачів i слухачів, рекомендації щодо використання інформаційнокомунікаційних технологій для викладання певних дисциплін і методів активного навчання в аудиторії. Нормативно має бути закріплене навантаження викладачів, розподіл функціональних обов'язків між зацікавленими підрозділами закладу освіти.

Висновки та напрями подальших досліджень. Наразі, ми отримаємо можливість дотриматись основних принципів, які передбачені положенням Меморандуму безперервної освіти Свропейської Комісії для професійного навчання державних службовців. Тобто передбачається налагодження повноцінної та ефективної системи професійного навчання для зазначеної категорії слухачів. Водночас імплементація сучасних інформаційних технологій і поява нових підходів до процесу навчання дає змогу викладачам впроваджувати найоптимальнішу методику для розвитку й набуття комунікативної компетентності 
слухачами. ЗН вдало поєднує онлайн навчання 3 присутністю викладача в аудиторному форматі.

Подальший напрям дослідження полягає у більш детальному розгляді переліку компетентностей державних службовців, які можуть розвиватися тільки за допомогою аудиторного навчання, компетентностей, які доцільно розвивати за допомогою самонавчання 3 використанням електронних ресурсів, а також компетентностей, які необхідно розвивати за допомогою навчання на робочому місці.

\section{Список використаних джерел}

1. Концепція реформування системи професійного навчання державних службовців, голів місцевих держадміністрацій, їх перших заступників та заступників, посадових осіб місцевого самоврядування та депутатів місцевих рад: розпорядження Кабінету Міністрів України від 01 грудня 2017 р. № 974-р. Офіиійний вісникУкраїни. 2018 р. № 3. С. 78 - 91.

2. Романовська О. О., Романовська Ю. Ю., Романовський О. О. Рекомендації щодо впровадження змішаного навчання у закладах фахової передвищої та вищої освіти. МОН України. Досвід вищої освіти Сполучених Штатів Америки XX-XXI століть. Книга 4. Особливості академічного (університетського) підприємництва у США другої половини XX- початку XXI століть : навч. посіб.Вид. НПУ ім. М. П. Драгоманова. Київ, 2020. 240 с.

3. Бугайчук К. Л. Змішане навчання: теоретичний аналіз та стратегія впровадження в освітній процес вищих навчальних закладів. Інформаційні технології $і$ засоби навчання. 2016. № 4, т. 54. С. 1 18.

4. Теорія та практика змішаного навчання : монографія / Кухаренко В. М. та ін. Харків: Міськдрук. НТУ ХПІ, 2016. 284 с.

5. Столяренко I. С. Особливості організації змішаного навчання у підготовці майбутніх учителів інформатики. Інформачійні технології в освіті. 2015. № 24. С. $138-146$.

6. Касьян С. П., Олійник В. В., Ляховська Л. Л. Науково-методичні основи впровадження технологій змішаного навчання в системі відкритої післядипломної освіти: методичний посібник. Київ: ДВНЗ «Університет менеджементу освіти», 2018. 312 с. 


\section{Науковий вісник : Державне управління №1 (7) 2021}

7. Теоретичні та організаційно-методичні засади проектування освітньої діяльності навчально-методичних установ цивільного захисту : монографія (з електрон. дод.) / Бегун В. В.; за заг. ред. Литвиновського Є.Ю. Вид. 2, переробл. Львів : Кругозір, 2017. 230 с.

8. Свсюков О. П, Гаваза А. О. Організаційно-методичні засади відбору змісту новітніх технологій підвищення кваліфікації управлінських кадрів сфери цивільного захисту. Науковий вісник: державне управління. №4(6). Київ: Інститут державного управління та наукових досліджень з цивільного захисту, 2020. С. 93 - 121.

9. Організація та проведення занять із застосуванням інноваційних методів : навчальний посібник / Терент'єва А. В. та ін. Київ: ІДУ НД ЦЗ, 2019. 139 с.

10. Про затвердження Положення про систему підготовки, спеціалізації та підвищення кваліфікації державних службовців і посадових осіб місцевого самоврядування: постанова Кабінету Міністрів України від 06 лютого 2019 р. № 106. Офіиійний вісник України. 2019. № 19. С. $43-52$.

11.Про освіту : Закон України від 5 вересня 2017 р. № 2145-VIII. Урядовий кур'єр. 2017. 4 жовт., редакція від 01.01.2021.

12. Про затвердження Положення про дуальну форму здобуття професійної (професійно-технічної) освіти: наказ М-ва освіти і науки України від 12 грудня 2019 р. № 1551. Офіuійний вісник Украӥни. 2020. № 18. - С. 150.

\section{References}

1.Rozporiadzhennia Kabinetu Ministriv Ukrainy Kontseptsiia reformuvannia sistemy profesiinoho navchannia derzhavnykh sluzhbovtsiv, holiv mistsevykh derzh administratsii, ikh pershykh zastupnykiv ta zastupnykiv, posadovykh osib mistsevoho samovriaduvannia ta deputativ mistsevykh rad 1 Hrudnia 2017 roku№ 974-r [The concept of reforming the system of professional training of civil servants, heads of local state administrations, their first deputies and deputies, local government officials and deputies of local councils: order of the Cabinet of Ministers of Ukraine dated December 1, 2017 № 974-r]. (2018, № 3).Official Gazette of Ukraine, pp. 78 - 91 [in Ukrainian].

2. Romanovska,O. O., Romanovska, Yu. Yu.,Romanovsky,O. O. (2020). Rekomendatsii shchodo vprovadzhennia zmishanoho navchannia $u$ zakladakh fakhovoii peredvyshchoii ta vyshchoi osvity. MON Ukrainy. 
Dosvid vyshchoi osvity Spoluchenykh Shtativ Ameryky XX-XXI stolit/Recommendations for the introduction of blended learning in institutions of professional higher and higher education.MES of Ukraine.The experience of higher education in the United States of America in the XX-XXI centuries].Kyiv:Vid. NPU them. MP Dragomanova. [in Ukrainian].

3. Bugaychuk, K. L. (2016).Zmishane navchannia: teoretichnii analiz ta stratehia vprovadzhennia $\mathrm{v}$ osvitnii protses vyshchykh navchalnykh zakladiv [Blended learning: theoretical analysis and strategy of introduction of higher educational institutions into the educational process]. Information technologies and teaching aids. 4,1-18[in Ukrainian].

4.eoriia ta praktyka zmishanoho navchannia: monohrafia[Theory and practice eblended learning: amonograph] / Kukharenko, V. M. and etc. Kharkiv: City Press. NTU KhPI[in Ukrainian].

5. Stoliarenko I. S.(2015). Osoblyvosti organizatsii zmishanohgo navchannia $\mathrm{u}$ pidhgotovtsi maibutnikh uchyteliv informatyky [The peculiarities of organizing the change of knowledge at the preparatory maybutny teachers of informatics]. Information technology in education.[in Ukrainian].

6. Kasyan S. P., Olyynik V. V., Lyakhovska L. L.(2018). Naukovometodychni osnovy vprovadzhennia tekhnologii zmishanogo navchannia v systemi vidkrytoi pisliadyplomnoi osvity: metodychnyi posibnyk [Scientific-methodical bases for the introduction of technologies of knowledge in the system of educational education: a methodical book]. Kiev: DVNZ "Un-t management. coverage "[in Ukrainian].

7. Lytvynovskyi C.Yu. and etc (2017). Teoretychni ta organizatsiinometodychni zasady proektuvannia osvitnoi diialnosti navchalnometodychnykh ustanov tsyvilnogo zakhystu: monografiia (zelektron.dod.) [Theoretical and organizational-methodical ambush of the design of the educational activity of the initial-methodical installations of the civil society: monograph (from electronic dood.)] /. view. 2, rerun. Lviv: Krugozir [in Ukrainian].

8. Evsyukov O. P., Gavaza A. O. (2020) Organizatsiino-metodychni zasady vidboru zmistu novitnikh tekh nologii pidvyshchennia kvalifikatsii upravlinskikh kadriv sfery zyvilnogo zakhystu [Organizationalmethodical ambush in the pick of new technologies to advance the quality of management personnel in the sphere of civil society]. Naukovyi visnik: state management. No. 4 (6) [in Ukrainian]. 
9. Terent'eva A. V. and etc (2019) Organizatsiia ta provedennia zaniat iz zastosuvanniam innovatsiinykh metodiv: navchalnyi posibnyk [Organizational and carrying out to take from the stasis of innovative methods: the main book]. K.: IDUTSZ [in Ukrainian].

10. Pro zatverdzhenni Polozhennia pro system pidhotovku, spetsializatsii ta pidvyshchennia kvalifikatsii derzhavnykh sluzhbovtsiv i posadovykh osib mistsevoho samovriaduvannia : Postanova Kabinetu Ministriv Ukrainy 6 lutoho 2019 roku№ 106 [On approval of the Regulations on the system of training, specialization and advanced training of civil servants and local government officials: Resolution of the Cabinet of Ministers of Ukraine of February 6, 2019 № 106]. (2019, № 19).Official Gazette of Ukraine, pp. 43 - 52[in Ukrainian].

11. Pro osvitu : Zakon Ukrainy 5 veresnia 2017 roku№ 2145-VIII [Law of Ukraine on Education September 5 2017, № 2145-VIII]. (2017, October 4). Governmentcourier[inUkrainian].

12. Pro zatverdzhennia Polozhennia pro dualnu formu zdobutia profesiinoi (profesiino-tekhnichnoi) osvity : Nakaz Ministersva osvity i nauky Ukrainy. 12 hrydnia 2019 roku№ 1551 [On approval of the Regulations on the dual form of obtaining professional (vocational) education: order of the Ministry of Education and Science of Ukraine of December 12, 2019 № 1551]. (2020, № 18).Official Gazette of Ukraine, p. 150 [in Ukrainian]. 


\title{
THE USAGE OF INNOVATIVE FORMS OF EDUCATION AND TEACHING METHODS FOR TRAINING CIVIL SERVANTS AND LOCAL GOVERNMENT OFFICIALS
}

\section{YurchenkoValerii}

\begin{abstract}
The article considers the forms of education for professional training of civil servants and local government officials (hereinafter - civil servants), in particular by institutional (full-time, distance, network, mixed, dual and workplace) form of education.

Based on the analysis of the provisions of the Memorandum of Continuing Education of the European Commission, it is established on what basic principles the new model of professional training of civil servants should be based - it is known from [1].

The main forms of education for this category of students, the advantages and disadvantages of full-time, distance, network, mixed, dual and workplace forms of education are analyzed in detail.

Some models of organization of mixed education for the training of civil servants are analyzed, in particular, the expediency of using the model of "inverted class" as one of the effective forms of education for this category of students is determined.

The recommendations of the Ministry of Science and Education of Ukraine on the introduction of mixed education in institutions of professional higher and higher education are considered [2].

An effective form of education for the training of civil servants is proposed, which takes into account all the advantages and eliminates the main disadvantages of the forms of education discussed in the article.

The directions of further research on improving the quality and efficiency of training of civil servants are identified, in particular in a more detailed consideration of the list of competencies of civil servants that can be developed only through classroom training, competencies that should be developed through self-study using electronic resources, and competencies need to be developed through on-the-job training.
\end{abstract}

Key words: training of civil servants, forms of education, mixed education, quality and efficiency of learning, models of mixed education. 